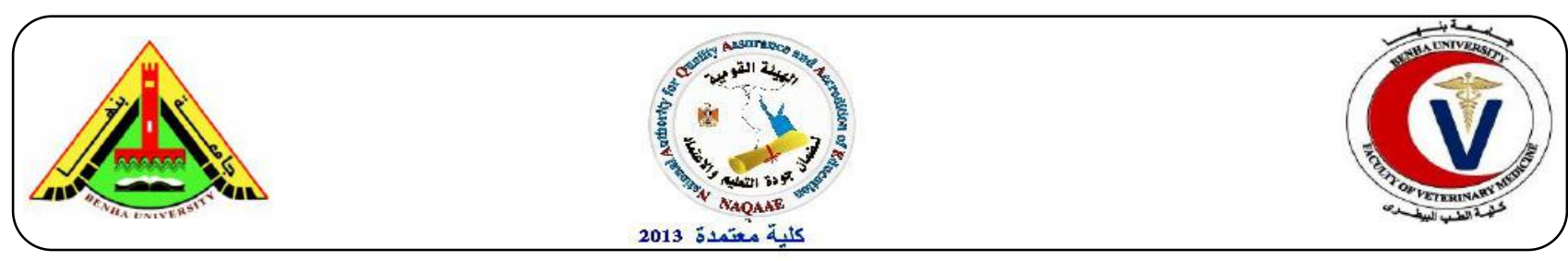

\title{
The Incidence of Sarcocystis in Slaughtered Food Animals
}

\author{
Hemmat M. Ibrahim ${ }^{1}$, Rasha El Sabagh ${ }^{1}$, Ahmed A. Wahba ${ }^{2}$, El Sayed A. Abd El Rahman ${ }^{1}$ \\ ${ }^{1}$ Department of Meat Hygiene and Control, Faculty of Veterinary Medicine, Benha University \\ ${ }^{2}$ Department of Parasitology, Animal Health Research Institute, Dokki, Giza
}

\begin{abstract}
A B S T R A C T
Sarcocystis affects the meat quality, rendering meat unmarketable and unacceptable to consumers. In the present study, total (2000) Slaughtered animals were examined during P.M inspection then the Macroscopic and Microscopic examinations were done for detection of Sarcocystis followed by Polymerase chain reaction (PCR) in El-Basateen automated abattoir in Cairo, Egypt. With special references to species, age, and sex of slaughtered animals, our study revealed that the higher incidence (macroscopic and microscopic) in old buffaloes (48.6\%-63.2\%) than young ones (41.2$53.8 \%$ ), respectively followed by cattle, sheep finally camel. In addition to the higher incidence (macroscopic and microscopic) in female buffaloes (25.8\%-36.2\%) than male ones (37\%-49.6\%), respectively followed by cattle, camel finally sheep. The PCR confirmed the presence of Sarcocystis in examined samples. SO that, the work recommended that Using of Microscopic examination and PCR for detection and confirmation of Sarcocystosis in abattoirs to avoid animals and human infections with such zoonotic parasite.
\end{abstract}

Keywords: Sarcocystis, meat, slaughtered food animals, parasites, PCR.

(http://www.bvmj.bu.edu.eg)

(BVMJ-35(1): 106-122, 2018)

\section{INTRODUCTION}

Meat is the most important source of animal protein for a wide range of consumers (FAO, 2013). Nowadays, there has been increasing demand for red meat consumption through the whole world. Consequently, Abattoirs can play the most important role in management and control of many of zoonotic diseases, particularly the sarcocystis which may transmitted to human by consumption of raw or under cooked meat (Mohamed. Sara, 2013).

The pathogenic Sarcocystis was distributed wide world and considered as meat borne pathogens which can enter the food chain any time between farms to fork. Human consumption of raw and under cooked meat can cause (meat- borne illness) either by the parasite itself and/or by their toxins toxicoinfection (Dubey et al., 2015).

Meat Sarcocystosis greatly lowers the meat quality, and meat grade rendering the meat and offal unmarketable and unacceptable to consumers., In addition to the great economic losses due to the condemnation of carcasses and /or offal in abattoirs, so that sarcocystosis was an important zoonotic food-borne parasitosis in humans and animals., (Ahmed et al., 2016). 
Humans Eating raw or undercooked beef parasitized with zoonotic mature Sarcocysts of $S$. hominis resulted in human intestinal Sarcocystosis, the Symptoms appear within 3 days after raw meat ingestion may due to toxins released from invading bradyzoites in raw meat, Diarrhea and abdominal pain were the most common symptoms (Ortega and Cama, 2018).

There are two types of Human Sarcocystosis distributed worldwide human intestinal and human muscular types (Dubey et al., 2015). Human Intestinal Sarcocystosis: takesplaces due to that the humans eat raw or undercooked meat with the sarcocystis cysts. Man becomes the definitive host after the ingestion of raw beef infested with Zoonotic S. hominis can cause food- borne illness, symptomized as: gastro enteritis, watery diarrhea, abdominal pain, nausea, vomiting, the infections are asymptomatic and selflimiting, (Fayer et al., 2015).

Zoonotic Sarcocystis spp. have been described in domestic cattle, buffaloes, camels, sheep, goats, pigs, deers, birds and wild animals, These zoonotic S. Species have considerable Veterinary, Economic and Public Health

Importance (Ghoneim et al., 2014). Sarcocystis have a high specificity for their host Spreading and infestations depend on many factors such as: parasite spp., sex, age, season, virulence of parasite, doses of infestation, immune status of animal, raising conditions, animal spp., pasture and grassing systems, the pollution with sporocysts and their resistance in the environment, other stress factors, etc, (Mehlhorn, 2016 ).

Meat Sarcocystosis Considered meat- borne illness during routine veterinary macroscopic \&microscopic P.M inspection of carcasses in abattoirs (Mohamed. Sara, 2013).

Nowadays, polymerase chain reaction (PCR) was the common confirmatory test, time/cost effective method used wide world (Gjerde et al., 2016).

Therefore the present study was aimed to detect the incidence of Sarcocystosis in Slaughtered animals at El-Basateen Automated Abattoir, Cairo, Egypt, using macroscopical and microscopical examinations followed by PCR for confirmation. Also, The Effect of Age and Sex on the incidence of Sarcocystis in Slaughtered food animals was discussed.

\section{Materials and methods}

\subsection{Samples collection:}

A total of 2000 Slaughtered food animals at El-Basateen Automated abattoir were examined during daily routine P.M inspection of buffaloes, cattles, sheep, and camels(500 each) were with different ages and sex (From January 2015 to february 2018) for detection of Sarcocystis using macroscopical, microscopical examination followed by PCR assay.

From Each animal five represented samples were examined esophagus, tongue, diaphragm, heart and Masseter muscles (50 gm of each) collected for the macroscopic and microscopic Sarcocysts examinations and PCR assay at Animal health Research institute, Parasitology Department, Dokky, Giza. The percentage of positive and negative samples microscopically were recorded. The positive Samples were kept at $-20{ }^{\circ} \mathrm{C}$ until applling of PCR assays as confirmatory test.

\subsection{Macroscopical examination:}

According to Ministry of Agriculture, Veterinary Services Authority of Egypt, (1986) the macroscopic sarcocysts were detected by gross inspection, palpation and incisions of the muscular tissues.

\subsection{Microscopical examination: (Ahmed et al., 2016)}


The Microscopic examination of Sarcocystis (Impression technique), (for both positive and negative macroscopically examined samples): stained with Giemsa stain, and examined by Light microscope $(100 \times)$ for microscopic Sarcocystis cysts.

\subsection{The Polymerase Chain Reaction:}

Singleplex PCR (Huissien et al., 2017)

\subsubsection{The Primer sequences of Sarcocystis species used for PCR:}

Application of PCR for identification of $18 \mathrm{~S}$ $r R N A$ as species specific gene of Sarcocystis species specific for cattle, camel and sheep was performed essentially by using primers as shown in table (1).

\subsubsection{DNA extraction (Silva et al., 2009):}

The samples were minced by an electric meat grinder and 25-30 $\mathrm{mg}$ of each minced tissue was used following the manufacturer's instructions of a commercial DNA extraction kit (Qiagen,Valencia, CA, USA). The samples were resuspended in $180 \mu \mathrm{l}$ ATL buffer and $20 \mu 1$ proteinase K (QIAamp DNA Mini Kit), and the protocol recommended for tissue samples was followed. All DNA extracts were stored at $-20{ }^{\circ} \mathrm{C}$ until used. This product was used as a template for PCR.

\subsubsection{DNA amplification:}

2.4.3.1. Amplification of $18 S$ rRNA gene of cattle\&buffaloe Sarcocystis (Daptardarkar et al., 2016):

The amplification was performed on a Thermal Cycler (Master cycler, Eppendorf, Hamburg, Germany). Accurately, PCR reactions were set up containing the PCR master mix of buffer, deoxynucleotides, DNA polymerase. To each PCR reaction, a $5 \mu 1$ of the genomic DNA (contain $\sim 25 \mathrm{ng}$ ) and 10 $\mu \mathrm{m}(1.0 \mu \mathrm{l})$ of the primer was added. The PCR reaction conditions were as follow: initial denaturation for $2 \mathrm{~min}$ at $94{ }^{\circ} \mathrm{C}$; 35 cycles with denaturation at $94{ }^{\circ} \mathrm{C}$ for $30 \mathrm{sec}$, cysts was applied by muscle squeeze method annealing at $52{ }^{\circ} \mathrm{C}$ for $30 \mathrm{sec}$ and extension at $72^{\circ} \mathrm{C}$ for $30 \mathrm{sec}$; and final extension for 10 $\min$ at $72{ }^{\circ} \mathrm{C}$.

Extracted DNA samples were elecrophoresed through $1.5 \%$ agarose solution in $1 \mathrm{x}$ TBE electrophoresis buffer at $80 \mathrm{~V}$ for 100 minutes. Finally, the gel was stained with ethidium bromide and captured as well as visualized on UV transilluminator. A $100 \mathrm{bp}$ plus DNA Ladder (Qiagen, Germany, GmbH) was used to determine the fragment sizes.

2.4.3.2. Amplification of $18 S$ rRNA gene of camel Sarcocystis (Motamedi et al., 2011):

The PCR was performed (30 $\mu 1$ reactions) using $1 \mu \mathrm{l}(10 \mathrm{pM})$ of each primer, $0.5 \mu \mathrm{l}$ Taq polymerase, $0.5 \mu \mathrm{dNTP}, 2 \mu \mathrm{MgCl} 2,10 \mu \mathrm{l}$ DNA, $3 \mu \mathrm{l}$ buffer $10 \times$ and $12 \mu$ distilled water. Reactions were carried out on an Eppendorf Master Cycler Gradient thermal cycler. The PCR required a preliminary denaturation at $94^{\circ} \mathrm{C}$ for $5 \mathrm{~min}$. The remaining PCR steps were 35 cycles at $94^{\circ} \mathrm{C}$ $(2 \mathrm{~min}), 57^{\circ} \mathrm{C}(30 \mathrm{sec}), 72^{\circ} \mathrm{C}(2 \mathrm{~min})$, with a single terminal step at $72^{\circ} \mathrm{C}(5 \mathrm{~min})$. The amplified DNA fragments were analyzed by $1.5 \%$ of agarose gel electrophoresis in $1 \mathrm{x}$ TBE buffer stained with ethidium bromide.

2.4.3.3. Amplification of $18 S$ rRNA gene of sheep Sarcocystis (Hamidinejat et al., 2014):

Briefly, amplification of the 18S rRNA gene was carriedout in 5011 reaction volumes containing $1 \mathrm{ll}$ of DNA template, 5 pmol of reverse and forward primers, $3.0 \mathrm{mM} \mathrm{MgCl} 2$, 5.011109 PCR Buffer, 200 lM of each dNTP and $2.5 \mathrm{U}$ Taq DNA polymerase. The thermal program of PCR was as follows: $94{ }^{\circ} \mathrm{C}$ for 5 min, 30 cycles of $94^{\circ} \mathrm{C}$ for $2 \mathrm{~min}$, annealing at $57{ }^{\circ} \mathrm{C}$ for $30 \mathrm{sec}$, and $72{ }^{\circ} \mathrm{C}$ for $2 \mathrm{~min}$, followed by a final extension step at $72^{\circ} \mathrm{C}$ for $5 \mathrm{~min}$. To verify the results, $10 \mathrm{ll}$ of each PCR product was electrophoresed in a $1 \%$ agarose gel, stained with safe stain and visualized on a UV transilluminator. The PCR products were identified by size using a 100 bp ladder 
(Fermentas). The expected PCR product had a length of $609 \mathrm{bp}$.

2.4.4 PCR Analysis: PCR products were finally analyzed by the agarose gel electrophoresis, banding patterns were documented, as in (Table A) and the positive PCR products were stored at $-20{ }^{\circ} \mathrm{C}$ till used for the Corresponding DNA sequencing.

2.4.5 DNA Sequencing: three representative samples from positive PCR products were selected for DNA sequencing in one direction using the forward primer (the same used in PCR amplification with primer 1). Sequencing reactions and protocols were performed according to manufacturer procedure using the ABI PRISM® 3100 Genetic Analyzer (Micron-Corp. Korea).

\subsection{Statistical analysis:}

According to method described by Kirkpatrick \& Feeney (2013).

\section{RESULTS}

3.1. Macroscopic examination of Sarcocystis: From the present study it was found that the large size Sarcocystis were (10-15 mm long $\mathrm{x}$ $0.7-6 \mathrm{~mm}$ width) and appeared as fusiform, oval, spindle, elongated, cucumber or rice seeds shaped, consists of opaque bodies, milky white in color, in between muscle bundles with the longitudinal axis of the muscle mass. In these organs, macrocysts were seen either just beneath the serosal surface, as in esophagus, or deep in the muscular layer, as in diaphragm and tongue and masseter muscles. The small sized Sarcocystis were $(1-5 \mathrm{~mm}$ long x $0.1-0.6$ $\mathrm{mm}$ width) and appeared as (Threads- like shaped) under perimysial connective tissue along the longitudinal axis of the myocytes as in Fig. (3): Macroscopic fusifomis White Sarcocystis (15m length) in Oesophagus of Buffaloe. Fig. (4): Macroscopic fusiformis shaped Sarcocystis cysts $10 \mathrm{~mm}$ length in oesophagus of buffaloe. Fig. (5): Macroscopic fusiform shaped Sarcocystis $15 \mathrm{~mm}$ length in Tongue of Buffaloes. Fig. (6): Macroscopic Heavy infestation of spindle shaped Creamy White Sarcocystis $7 \mathrm{~mm}$ length in esophagus muscle of Cattle, Fig. (7): Macroscopic spiral shaped White Sarcocystis $6 \mathrm{~mm}$ length in Masseter muscle of Cattle Fig. (8): Macroscopic White cylindrical shaped Sarcocystis $9 \mathrm{~mm}$ length in esophagus of Camel.

3.2 Microscopic examination of Sarcocystis:

It found that mature Sarcocysts contained numerous bradyzoites and many peripheral metrocytes; all were (banana or crescentshaped) with the anterior end more pointed than the posterior one. As in Fig (9): Bradyzoites (b) (banana-shaped) and metrocytes (m) (stumped and less curved) from Sarcocytis cyst of buffaloes (Giemsa stain) (X 1200). Fig. (10): Microscopic Stumped shaped Sarcocystis cyst in esophagus of buffaloes (X100) (300 X $91 \mu \mathrm{m})$ .Fig. (11): Microscopic Elongated cyst with rounded ends in diaphragm of camel. (X 100) (950 X $150 \mu \mathrm{m}$. Fig. (12): Microscopic Spindle shaped Sarcocystis cyst in esophagus of cattle. (X 100) (900 X $186 \mu \mathrm{m})$.Fig. (13): Microscopic Spiral shaped Sarcocystis cyst in diaphragm of cattle. (X 100). Outer layer appeared homogenous non-striated (arrows). (870 X $220 \mu$ m. Fig. (14): Microscopic Spiral shaped and elongated Sarcocystis cyst in masseter muscle of sheep (X 100). Outer layer appeared striated with perpendicular rods (arrows). (1432 X 190).

3.3 Incidence of Sarcocystis depending on Sex, in Table (2) and fig. (1):

Revealed that: The average incidence of both Macroscopic and Microscopic sarcocyts was for male $25.8 \%$ \& $36.2 \%$, for female $37 \%$ \& $49.6 \%$. Concerning to cattle the average incidence For male it was: $23.40 \% \& 28.60$ $\%$, for female cattle it was: $32.60 \%$ \& $44.60 \%$, In camel the average incidence For male it was $16.60 \%$ \& $25.80 \%$, for female it 
was $22.2 \% \& 30 \%$, regarding to sheep the average incidence For male it was: $12 \%$ $\& 16.60 \%$, for female it was $15.40 \%$ \& $24.80 \%$.

3.4. Incidence of Sarcocystis depending to Age, in Table (3) and fig. (2):

It was found that the incidence of sarcocystis achieved for old buffaloes was: $48.6 \%$ macroscopic \& $63.20 \%$ microscopic, for young buffaloes it was: $41.20 \% \& 53.80 \%$, regarding to old cattle it was: $32.80 \%$ $\& 43.20 \%$, for young cattle it was: $23.20 \% \&$ $29.60 \%$, in old camel it was: $13.6 \%$ \& $25.8 \%$, in young camel it was:5.8 \&13\%,, in old sheep it was: $13.20 \% \& 27.20 \%$, in young sheep it was: $7.80 \% \& 17.80 \%$.

3.5. PCR Reading results (photograph 15, 16, and 17) \& (table 1):

3.5.1. Incidence of Sarcocystis in cattle and buffaloes using PCR:

It was found that three samples out of five confirmed positive for cattle while four samples out of five were confirmed positive for buffaloes as resulted in Photograph (15): Agarose gel electrophoresis of PCR of $18 \mathrm{~S}$ rRNA gene (570 bp) for characterization of Sarcocystis species detected in cattle and buffaloe tissues.

3.5.2. Incidence of Sarcocystis in camels using PCR:

It was achieved that two samples out of five confirmed positive as resulted in Photograph (16): Agarose gel electrophoresis of PCR of 18S rRNA gene (539 bp) for characterization of Sarcocystis species detected in camel tissues.

3.5. 3. Incidence of Sarcocystis in sheep using PCR:

It was found that, four samples out of five confirmed positive as resulted in Photograph (17): Agarose gel electrophoresis of PCR of 18S rRNA gene (609 bp) for characterization of Sarcocystis species detected in sheep tissues.

Table 1: Target genes and primers used in PCR

\begin{tabular}{|c|c|c|c|c|}
\hline Target genes & Primers & Oligonucleotide sequence $\left(5^{\prime} \rightarrow 3^{\prime}\right)$ & $\begin{array}{l}\text { Product size } \\
\text { (bp) }\end{array}$ & Reference \\
\hline \multirow{2}{*}{$\begin{array}{c}18 S \text { rRNA } \\
\text { (Cattle\&Buffaloe) }\end{array}$} & A18S (F) & 5' CGAATGGCTCATTAAAACAG '3 & \multirow[b]{2}{*}{570} & \multirow{2}{*}{$\begin{array}{l}\text { Daptardarkar } \\
\text { et al. (2016) }\end{array}$} \\
\hline & $\begin{array}{c}\text { A18S } \\
(\mathrm{R})\end{array}$ & 5' CCAACTACGAGCTTTTTAAC '3 & & \\
\hline \multirow{2}{*}{$\begin{array}{c}18 S \text { rRNA } \\
\text { (Camel) }\end{array}$} & $\mathrm{A} 18 \mathrm{~S}(\mathrm{~F})$ & 5' GCACTTGATGAATTCTGGCA '3 & \multirow[b]{2}{*}{539} & \multirow{2}{*}{$\begin{array}{l}\text { Motamedi et } \\
\text { al. (2011) }\end{array}$} \\
\hline & $\begin{array}{l}\text { A18S } \\
(\mathrm{R})\end{array}$ & 5' CACCACCCATAGAATCAAG ' 3 & & \\
\hline $18 S$ rRNA & $\operatorname{Sar}(F)$ & 5' GCACTTGATGAATTCTGGCA '3 & \multirow{2}{*}{609} & \multirow{2}{*}{$\begin{array}{l}\text { Paikari et al. } \\
\qquad(2008)\end{array}$} \\
\hline (Sheep) & $\operatorname{Sar}(\mathrm{R})$ & 5' CACCACCCATAGAATCAAG ' 3 & & \\
\hline
\end{tabular}


Table 2: Incidence of macroscopic and microscopic Sarcocystis in slaughtered food animals according to the Sex. (No. $=500)$.

\begin{tabular}{|c|c|c|c|c|c|}
\hline \multirow{3}{*}{ Species } & \multirow{3}{*}{ Samples } & \multicolumn{2}{|l|}{ Male } & \multicolumn{2}{|c|}{ Female } \\
\hline & & $+\mathrm{ve}$ & $+\mathrm{ve}$ & $+\mathrm{ve}$ & $+\mathrm{ve}$ \\
\hline & & Macroscopic & Microscopic & Macroscopic & Microscopic \\
\hline \multirow[b]{6}{*}{ Buffalo } & Oesophagus & 37 & 52 & 45 & 60 \\
\hline & Tongue & 30 & 46 & 40 & 56 \\
\hline & Diaphragm & 27 & 33 & 37 & 45 \\
\hline & Heart & 15 & 20 & 26 & 37 \\
\hline & Masseter Ms. & 20 & 30 & 37 & 50 \\
\hline & Average & $25.8 \%$ & $36.2 \%$ & $37 \%$ & $49.6 \%$ \\
\hline \multirow{6}{*}{ Cattle } & Oesophagus & 38 & 44 & 41 & 60 \\
\hline & Tongue & 25 & 30 & 35 & 51 \\
\hline & Diaphragm & 21 & 27 & 33 & 40 \\
\hline & Heart & 13 & 17 & 23 & 30 \\
\hline & Masseter Ms. & 20 & 25 & 31 & 42 \\
\hline & Average & $23.4 \%$ & $28.6 \%$ & $32.6 \%$ & $44.6 \%$ \\
\hline \multirow{6}{*}{ Camel } & Oesophagus & 24 & 35 & 29 & 34 \\
\hline & Tongue & 17 & 25 & 23 & 30 \\
\hline & Diaphragm & 14 & 21 & 20 & 27 \\
\hline & Heart & 12 & 19 & 18 & 26 \\
\hline & Masseter Ms. & 16 & 29 & 21 & 33 \\
\hline & Average & $16.6 \%$ & $25.8 \%$ & $22.2 \%$ & $30 \%$ \\
\hline \multirow{6}{*}{ Sheep } & Oesophagus & 17 & 23 & 25 & 35 \\
\hline & Tongue & 13 & 17 & 17 & 29 \\
\hline & Diaphragm & 11 & 14 & 12 & 18 \\
\hline & Heart & 7 & 11 & 8 & 13 \\
\hline & Masseter Ms. & 12 & 18 & 15 & 29 \\
\hline & Average & $12 \%$ & $16.6 \%$ & $15.4 \%$ & $24.8 \%$ \\
\hline
\end{tabular}


Table 3: Incidence of macroscopic and microscopic Sarcocystis in slaughtered food animals according to the age (No. $=500$ ).

\begin{tabular}{|c|c|c|c|c|c|}
\hline \multirow{3}{*}{ Species } & \multirow{3}{*}{ Sampels } & \multicolumn{2}{|c|}{ Old age } & \multicolumn{2}{|c|}{ Young age } \\
\hline & & +ve & +ve & +ve & +ve \\
\hline & & macroscopic & microscopic & macroscopic & microscopic \\
\hline \multirow{7}{*}{ Buffaloe } & Oesophagus & 57 & 76 & 51 & 65 \\
\hline & Tongue & 50 & 69 & 45 & 60 \\
\hline & Diaphragum & 48 & 68 & 42 & 54 \\
\hline & Heart & 43 & 42 & 29 & 33 \\
\hline & Masseter ms. & 45 & 61 & 39 & 57 \\
\hline & Average & $48.6 \%$ & $63.2 \%$ & $41.2 \%$ & $53.8 \%$ \\
\hline & Oesophagus & 44 & 54 & 32 & 35 \\
\hline \multirow{4}{*}{ Cattle } & Tongue & 36 & 46 & 29 & 32 \\
\hline & Diaphragum & 33 & 43 & 28 & 32 \\
\hline & Heart & 24 & 35 & 12 & 24 \\
\hline & Masseter ms. & 27 & 38 & 15 & 25 \\
\hline \multirow{8}{*}{ Camel } & Average & $32.8 \%$ & $43.2 \%$ & $23.2 \%$ & $29.60 \%$ \\
\hline & Oesophagus & 19 & 41 & 9 & 18 \\
\hline & Tongue & 15 & 29 & 7 & 12 \\
\hline & Diaphragum & 18 & 19 & 6 & 10 \\
\hline & Heart & 8 & 13 & 2 & 9 \\
\hline & Masseter ms. & 13 & 27 & 5 & 16 \\
\hline & Average & $13.6 \%$ & $25.8 \%$ & $5.8 \%$ & $13 \%$ \\
\hline & Oesophagus & 16 & 33 & 12 & 22 \\
\hline \multirow{5}{*}{ Sheep } & Tongue & 14 & 30 & 9 & 21 \\
\hline & Diaphragum & 13 & 27 & 8 & 20 \\
\hline & Heart & 8 & 22 & 4 & 12 \\
\hline & Masseter ms. & 5 & 24 & 6 & 14 \\
\hline & Average & $13.2 \%$ & $27.2 \%$ & $7.8 \%$ & $17.8 \%$ \\
\hline
\end{tabular}




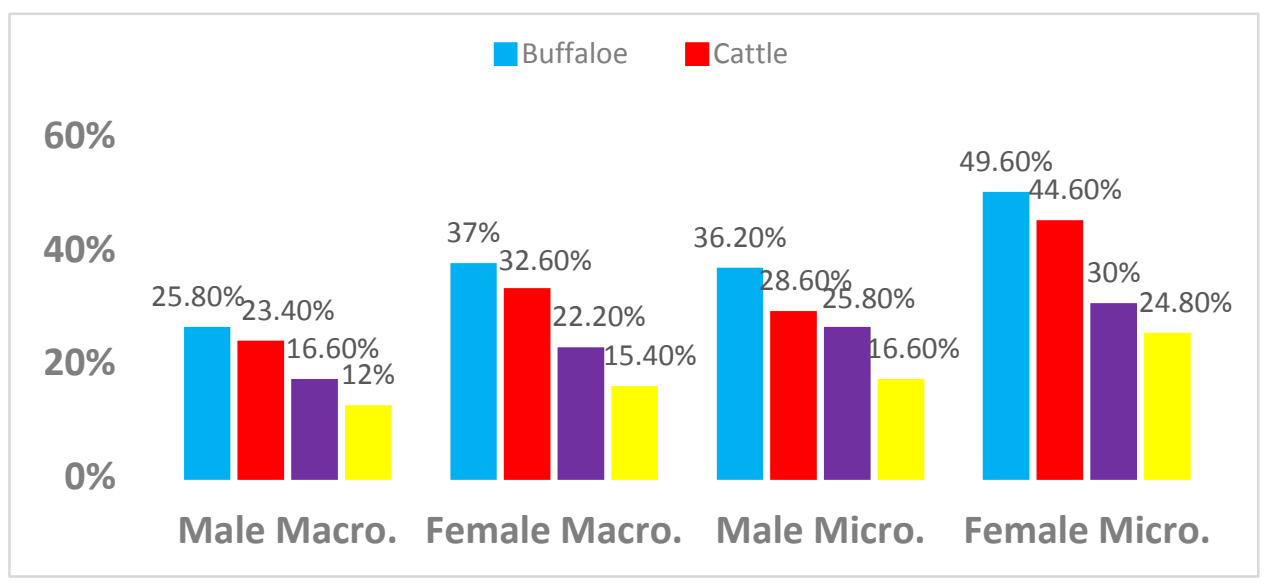

Fig.1. Incidence of macroscopic and microscopic Sarcocystis in slaughtered food animals according to the Sex.

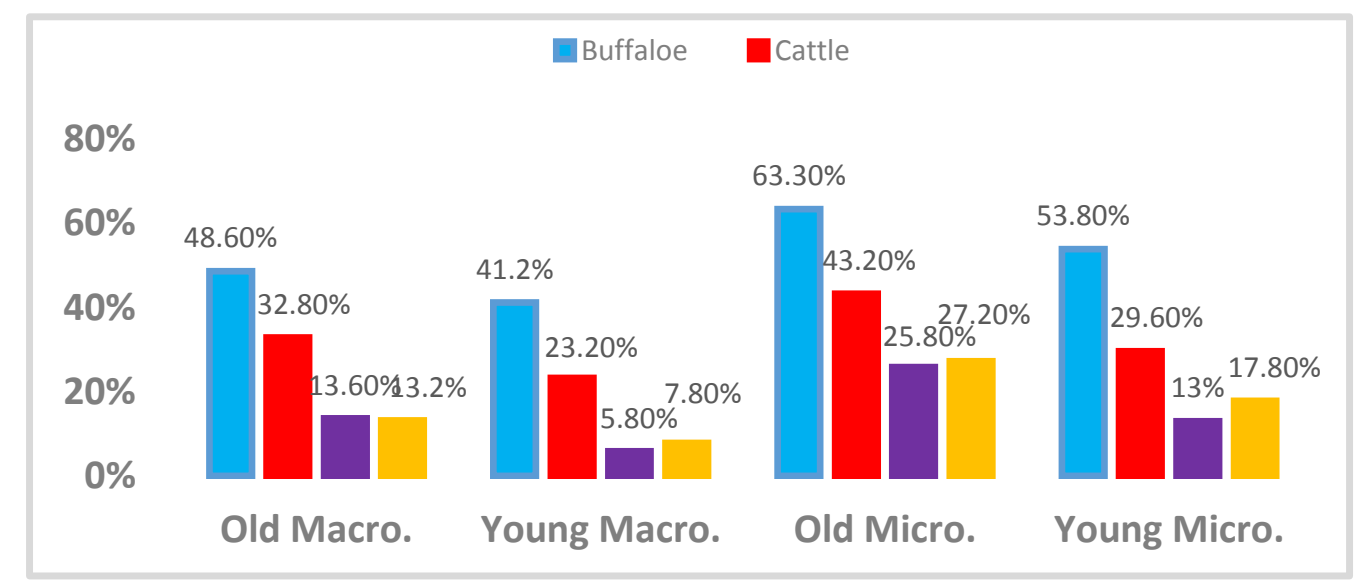

Fig.2. Incidence of macroscopic and microscopic Sarcocystis in slaughtered food animals according to the age.

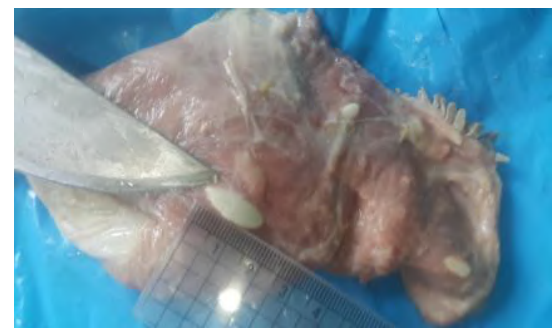

Fig.3. Macroscopic fusifomis White Sarcocystis (15mm length) in esophagus of Buffaloes 


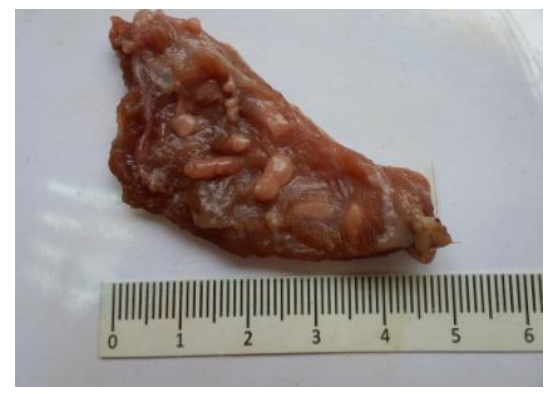

Fig.4. Macroscopic fusiformis shaped Sarcocystis cysts $10 \mathrm{~mm}$ length in esophagus of buffaloes.

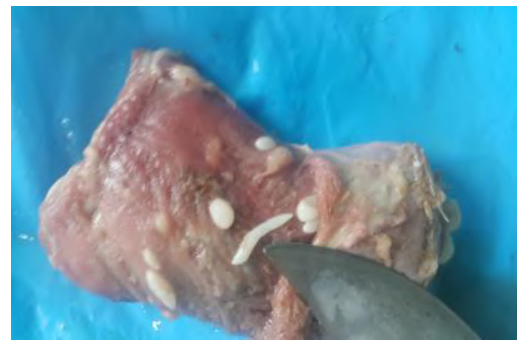

Fig.5. Macroscopic fusiformis shaped Sarcocystis $15 \mathrm{~mm}$ length in Tongue of buffaloes.

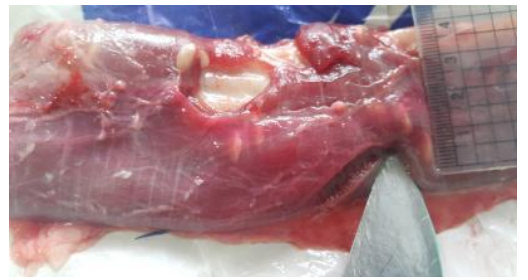

Fig.6. Macroscopic Heavy infestation of spindle shaped Creamy White Sarcocystis $7 \mathrm{~mm}$ length in esophagus muscle of Cattle

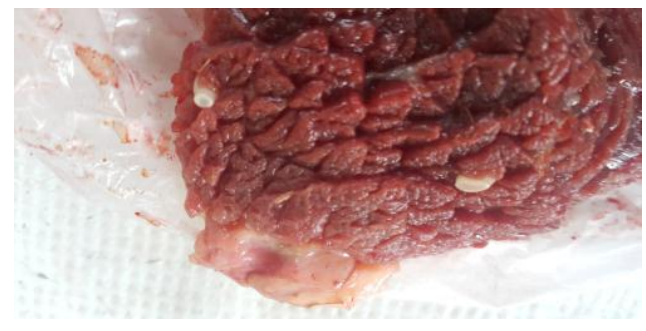

Fig.7. Macroscopic spiral shaped White Sarcocystis $6 \mathrm{~mm}$ length in Masseter muscle of Cattle

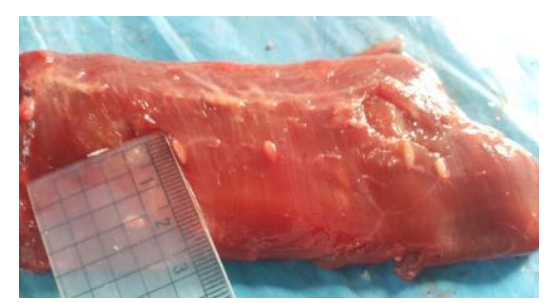

Fig.8. Macroscopic White cylindrical shaped Sarcocystis $9 \mathrm{~mm}$ length in esophagus of Camel. 


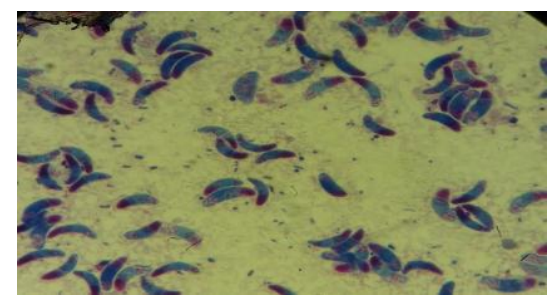

Fig.9. Bradyzoites (b) (banana-shaped) and metrocytes $(\mathrm{m})$ (stumped and less curved) from Sarcocytis cyst of buffaloe (Giemsa stain) (X 1200).

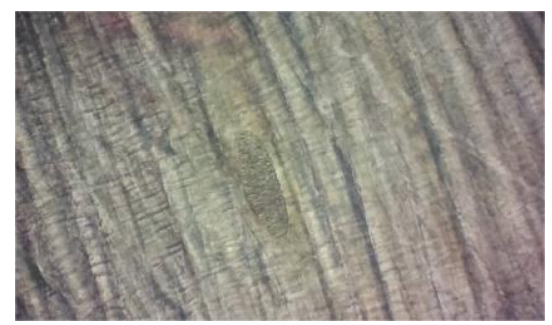

Fig.10. Microscopic Stumped shaped Sarcocystis cyst in oesophagus of buffaloe (X100) (300 X 91 $\mu \mathrm{m})$.

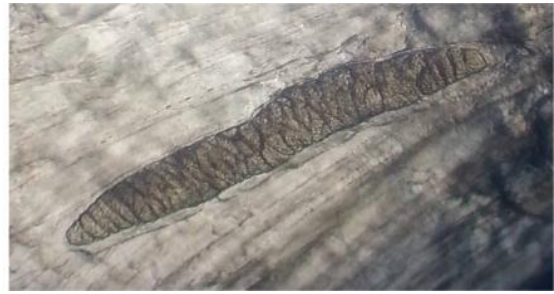

Fig.11. Microscopic Elongated cyst with rounded ends in diaphragm of camel. (X 100) (950 X 150 $\mu \mathrm{m}$.

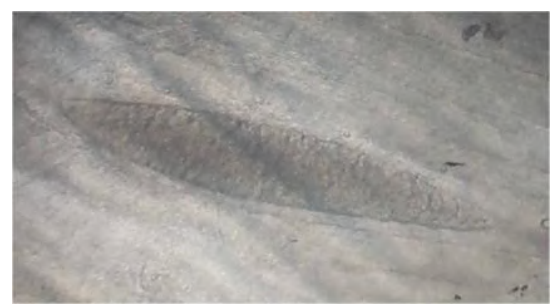

Fig.12. Microscopic Spindle shaped Sarcocystis cyst in oesophagus of cattle. (X 100) (900 X 186 $\mu \mathrm{m})$.

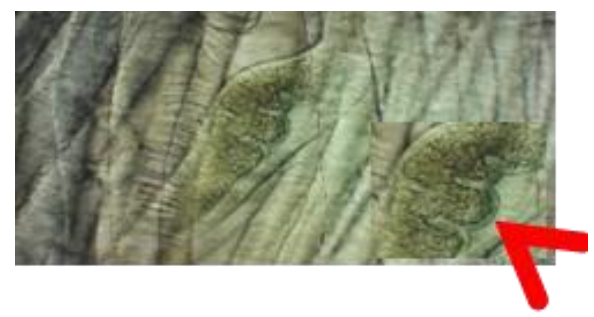

Fig.13. Spiral shaped Sarcocystis cyst in diaphragm of cattle. (X 100). Outer layer appeared homogenous non-striated (arrows).(870 X $220 \mu \mathrm{m}$. 


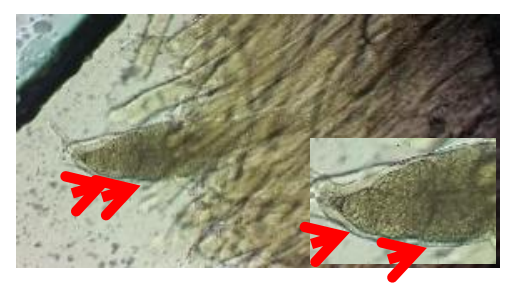

Fig.14. Spiral shaped and elongated Sarcocystis cyst in masseter muscle of sheep (X 100). Outer layer appeared striated with perpendicular rods (arrows). (1432 X 190) $\mu \mathrm{m}$.

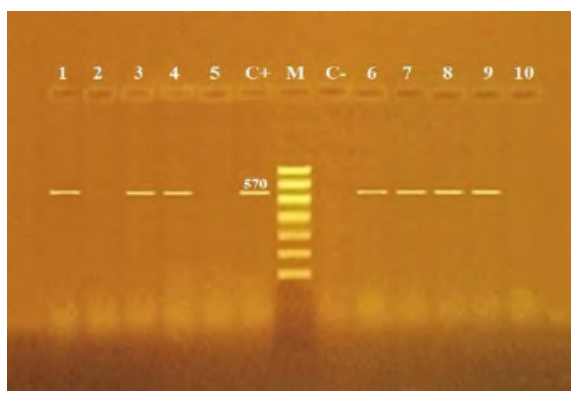

Fig.15. Agarose gel electrophoresis of PCR of $18 \mathrm{~S}$ rRNA gene (570 bp) for characterization of Sarcocystis species detected in cattle and buffaloes tissues:

Lane M: 100 bp ladder as molecular size DNA marker.

Lane C+: Control positive Sarcocystis species for 18S rRNA.

Lane C-: Control negative.

Lanes 1, $3 \&$ 4: Positive bands for bovine specimens.

Lanes $2 \& 5$ : Negative bands for bovine specimens.

Lanes 6, 7, 8 \& 9: Positive bands for buffalo specimens.

Lane 10: Negative band for buffalo specimens.

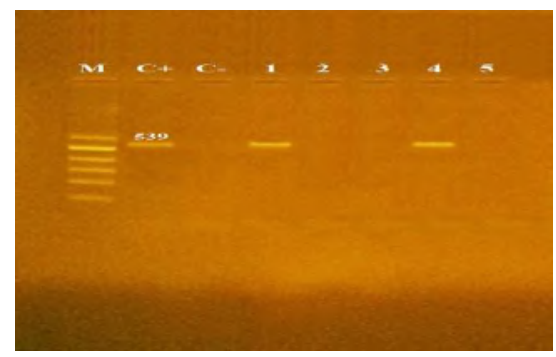

Fig.16. Agarose gel electrophoresis of PCR of $18 \mathrm{~S}$ rRNA gene (539 bp) for characterization of Sarcocystis species detected in camel tissues:

Lane M: 100 bp ladder as molecular size DNA marker.

Lane C+: Control positive Sarcocystis species for 18S rRNA.

Lane C-: Control negative.

Lanes $1 \&$ 4: Positive bands for camel specimens.

Lanes 2, 3 \& 5: Negative bands for camel specimens. 


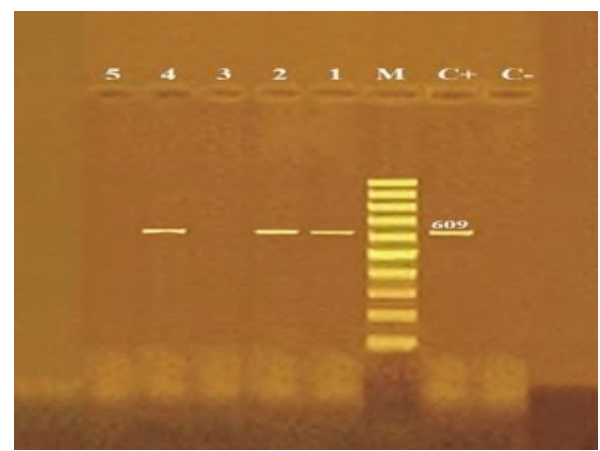

Fig.17. Agarose gel electrophoresis of PCR of $18 \mathrm{~S}$ rRNA gene (609 bp) for characterization of Sarcocystis species detected in sheep tissues:

Lane M: 100 bp ladder as molecular size DNA marker.

Lane C+: Control positive Sarcocystis species for 18S rRNA.

Lane C-: Control negative.

Lanes 1, 2 \& 4: Positive bands for sheep specimens.

Lanes 3 \& 5: Negative bands for sheep specimens.

\section{DISCUSSION}

\subsection{Macroscopic Sarcocysts Morphology:}

The present work found that as in fig. (3), (4), (5), (6) and (7), the macroscopic examination of buffaloes and cattle revealed that the large size Sarcocystis were 5-15 mm long x $0.7-6$ $\mathrm{mm}$ width and appeared as fusiformis or oval or cucumber or rice seeds spindle shaped white or creamy colour the small size Sarcocystis were $1-5 \mathrm{~mm}$ long x $0.1-0.6$ $\mathrm{mm}$ and appeared as threads- like shaped under perimysial connective tissue along the longitudinal axis of the myocytes. Our results was nearly similar to the same macroscopic pictures described by El-Dakhly et al. (2011) in Egypt.

Concerning to camel, the results revealed that as in: Fig. (8): the cylindrical or elongated white Sarcocystis or white creamy Sarcocystis $7 \mathrm{~mm}$ length in esophagus muscle of camel. These results are similar to the same results obtained by Motamedi et al. (2011).
Regarding to sheep, the macroscopic Sarcocystis appeared as Oval or Rice- like shaped Sarcocystis $4.5 \mathrm{~mm}$ length in esophagus of Sheep. The same results were obtained by EL-Mishmishy (2017) in Dakahlia provence.

\subsection{Microscopic Sarcocysts Morphology:}

The present study revealed that as in Fig.(9) the presence of abundant of (banana-shaped) Bradyzoites and metrocytes $(\mathrm{m})$ (stumped and less curved) from Sarcocytis cyst of buffaloe (Giemsa stain)(X 1200), Fig. (10): Microscopic Stumped shaped Sarcocystis cyst in esophagus of buffaloes (X100) (300 X 91 $\mu \mathrm{m})$. The current study results nearly similar to these obtained by El-Dakhly et al., (2011) in Egypt, who found that fusiformis and stumped shaped Sarcocystis in esophagus of buffaloes.

Concerning to cattle, the microscopic cysts appeared as in Fig. (12): Microscopic Spindle shaped Sarcocystis cyst in esophagus of cattle. (X 100) (900 X $186 \mu \mathrm{m})$.Fig. (13): Microscopic Stumped shaped Sarcocystis cyst 
in heart of cattle. (X 100)(430 X 140 $\mu \mathrm{m})$.These results are similar to the results obtained by Badawy et al. (2012) at Sharkia Province, Egypt.

Regarding to camel, the study achieved that as in Fig. (11): Microscopic Elongated Sarcocystis cyst with two rounded ends in esophagus of camel. (X 100) (1200 X 180 $\mu \mathrm{m})$.the present results in camel are similar to the results obtained by Wahba et al. (2014).

In sheep, it was found that the microscopic Sarcocystis as in Fig. (14): Spiral and elongated Sarcocystis cyst in masseter muscle of sheep (X 100).Outer layer appeared striated with perpendicular rods (arrows). $(1432$ X $190 \mu \mathrm{m})$. These results are similar to the same results obtained by EL-Mishmishy (2017).

\subsection{Incidence of Sarcocystis depending on Sex of animals in Table (1) and fig. (1):}

In the present study, The results achieved that: higher incidence in female buffaloes than in male, for female buffaloes the incidence of macroscopic and microscopic it was: $37 \%$ \& $49.6 \%$., while in male buffaloes it was: $27 \% \& 48.8 \%$, Nearly the same results agreed with the previous studies obtained by: Abu-Elwafa et al. (2012) with (48 \%) incidence in Elsharkia province. high incidence was recorded by Ghonim et al. (2014) with (69\%) in Cairo and Giza abattoirs, Egypt. Hanan. (2016) (69\%) in female and $(62 \%)$ in male buffaloes In BeniSuef provence. and El-Dakhly et al. (2011) $(78.9 \%)$ in Beni-Suef Governorate, Egypt. On contrary to very low incidence recorded by Ahmed et al. (2016) with incidence of $(8.33 \%)$ at El-kharga abattoir-New vally province, Egypt.,

In different organs, the highest incidence of Sarcocystis macroscopic and microscopic in buffaloes was recorded in esophagus $60 \%$ followed by tongue $56 \%$ and, diaphragm $50 \%$ masseter $45 \%$, finaly heart muscles $37 \%$ So that the esophagus was considered the most common sites for sarcocystosis in buffaloes this agreed with previous studies obtained by Ghoneim et al., (2014), who found that, 63\% in esophagus, $58 \%$ tongue, $51 \%$ diaphragm and $44 \%$ masseter.

Higher incidence in organs were in esophagus this agreed with previous studies obtained by: Ahmed et al. (2016) with $76.3 \%$ oesophagus incidence at Elgharga abattoirNew vally, province And Ghonim et al.(2014) $69 \%$ in Egypt.

Concerning to cattle, the present results revealed higher incidence in female than in male, for female cattle it was: $32.60 \%$ and $44.60 \%$., for male cattle were: $23.40 \%$ and $28.60 \%$. This nearly agreed with previous studies obtained by: Abu-Elwafa et al. (2012) $48.36 \%$., Korany. Hanan, (2016) $50 \%$ in female and $45 \%$ in male cattle, Ghonim et al. (2014) 60\%, and Ali (2013) 68.9\% in Qena province. Egypt.

Regarding to camel the present work recorded higher incidence in female than in male for female it was: $16.80 \%$ macroscopic and $30 \%$ microscopic. for male The incidence was: $16.60 \%$ macroscopic and $25.80 \%$ microscopic., This present results revealed that the higher incidence in female than in male camels in oesophagus this nearly agreed with previous studies recorded by: Ali (2013) 48.7\% in Qena province., Wahba et al. (2014) $68.8 \%$ in El- Basateen abattoir Egypt.,Abd-Elmalek et al.(2015)55 \% in Assuit provence, Egypt. While this results disagreed with these reported by Al-Ani and Amr (2017) 6.8\% in Jourdan.

Regarding to sheep the present results achieved that higher incidence in female than in male, for female it was: 
$11.20 \%$ macroscopic and $18.80 \%$ microscopic. For male it was: $12.09 \%$ macroscopic and $16.60 \%$ microscopic., These results agreed with the previous studies obtained by Korany. Hanan, (2016) 24\% in female and $21 \%$ in male sheep in Beni-Suef provence.

The present work results disagreed with the very higher incidence of sarcocystosis in sheep recorded by Ali (2013) 65.6\% in Qena province, (El- Mishmishy 2017) $95.37 \%$ microscopic incidence and $0.74 \%$ macroscopic incidence in Al-Dakahlia province.

In our study The incidence in female animals was higher than in male ones due to female is mainly with low immunity due to pregnancy and lactation stress which suppressed immune system this agreed with these recorded by Korany .Hanan, (2016) .

\subsection{Incidence of Sarcocystis depending on} Age in Table (2) and fig. (2):

The results found that higher incidence in old buffaloes than in young, for old buffaloes it was: $48.6 \%$ and $63.20 \%$, while in young the incidence of macroscopic and microscopic was: $41.20 \%$ and $53.80 \%$.

The results are nearly agreed with these obtained by Hanan (2016) 78\% in old \& 67 $\%$ in young buffaloes, El-Seify et al. (2014) with $68.2 \%$ in old \& $17.2 \%$ in young in ElGharbia province, Egypt.

Regarding to cattle our results revealed that higher incidence in old cattle than in young. For old the incidence it was: $32.80 \% \& 43.20$ $\%$., in young it was: $23.20 \% \& 29.60 \%$.

This results agreed with previous studies obtained by Korany. Hanan, (2016) 58\% in old \& $37 \%$ in young cattle In Beni-Suef province.
Concerning to camel our results revealed that higher incidence in old camel than in young. For old camel, it was: $13.6 \%$ macroscopic $\$ 25.8 \%$ microscopic. For young it was: $5.8 \% \& 13 \%$. The results agreed with previous studies obtained by: Abd-Elmalek et al. (2015) with incidence 55\% in Assiut province, Wahba et al. (2014) $68.8 \%$ in ElBasateen abattoir Egypt.

In sheep the results revealed higher incidence in old sheep than in young for old it was: $13.20 \%$ macroscopic \& $27.20 \%$ microscopic. For young it was: $7.80 \%$ \& $17.80 \%$. This agreed with the results obtained by Korany. Hanan, (2016) who recorded 32\% in old \& $23 \%$ in young sheep in Beni-Suef province.

The higher incidence in old animals than in young may be due to in old ages the longer and repeated exposure periods to the millions infectious sporocysts, Contaminated the feed, drinking water, and pastures. The continous close -contact between animals and final hosts (dogs and cats) abundantly was keeping the life cycle of Sarcocystis, also, the high resistance of sporocysts to harsh environmental conditions which is the main sources of infestation for animals. So that, the higher incidence in slaughtered food animals, also due to lower immunity in old ages Ahmed et al. (2016).

Moreover El-Basateen abattoir is located in a desert area where stray dogs and cats were abundant Which continouslly shedding millions of infective sporocysts in the environment.,contaminating the food and water of food animals.

4.5. PCR Reading Results in (photograph (1), (2) and (3) :

In the present study the PCR amplification of the 18S rRNA gene region was conducted to confirm the positive samples., PCR achieved 
that the sarcocystis in buffaloes four samples out of five was confirmed positive followed by cattle three samples out of five was confirmed positive, in sheep three samples out of five was confirmed positive, finally camel two samples out of five were confirmed positive. The present PCR results agreed with The nearly Similar previous results obtained by Abd-ElNaby et al.(2016)70.9\% incidence for buffaloe at Alexandria province, EL Seify et al.(2014) 99\% incidence in El Mahala Abattior at El-Gharbia province Egypt., and Ashmawy et al.(2014)67.6\%incidence for buffaloes at Alexandria province, Egypt.

\section{Conclusion}

Our study concluded that the higher incidence of Sarcocystis in El -Basateen abattior were achieved in female than male, also in old than young animals, moreover the microscopic was higher than macroscopic Sarcocystis incidence. Which have puplic health and economic losses.SO that the Routine P.M meat inspections in Abattoirs in Egypt were un-sufficient for detecting Sarcocystosis, this may be due to the presence of more hidden microscopic Sarcocysts, which unapparent macroscopically. Therefore, we strongly recommended that the using of microscopical examination and molecular characterization (PCR) for Sarcocystis diagnosis in abatiors, to avoid human infection of such zoonotic parasites and prevent \& control the sarcocystosis.

\section{REFERENCES}

Abd-Elmalek, B.S.; Abed, G.H.; Mandour, A.M. (2015): Study on Sarcosystis Sp. By Light and Electron Microscopy in Camel Muscles at Assiut Governorate. J Vet. Sci, Technol 6:266. doi:10.4172/2157-7579.1000266.

Abu-Elwafa, S.A.; Al-Araby; M.A. and
Abbas, I. E. A. (2012): Comparative ultrastructure of two types of Sarcocystis spp. of water buffaloes (Bubalus bubalis) from Egypt. Proceedings of the 5th Scientific 1-3 October Conference of Animal Wealth Research in the Middle East and North Africa, Faculty of Agriculture, Cairo University, Giza, Egypt, pp: 48-59.

Ahmed, A.M.; Elshraway, N.T. and Youssef, A. (2016): Survey on Sarcocystis in bovine carcasses slaughtered at the municipal abattoir of El-Kharga, Egypt, Veterinary World, 9(12): 14611465.

Al-Ani, F.K. and Amr, Z. (2017): Sarcocystis spp Prevalence in Camel Meat in Jordan. Dairy and Vet Sci, J., 4(4): 555643.

Ali, A.A. (2013): thesis The prevalence of some parasitic infestations in tissue of slaughtered animals in Qena Governate., Ph.sc,Assuit Univ.

Ashmawy, k.; Abu-Akkada, Somia,S.; Ghashir, M (2014):Prevalence and molecular characterization of Sarcocystis species in water buffaloes (Bubalus bubalus) in Egypt. Trop Animl Health Prod.

Badawy, A.I.; Abouzaid, N.Z. and Ahmed, H.A. (2012): Sarcocystis hominis and other Sarcocystis species infecting cattle in Sharkia province, Egypt. $J$. Am. Sci., 8(8): 271-275.

Daptardar, B.B.S.; Rabinder S.A. and Jatinder, P.S.G. (2016): Prevalence and first molecular identification of Sarcocystis species in cattle and water buffaloes in India.Acta Parasitologica, 61(3): 523-528.

Dubey, J. P.; Calero-Bernal, R.; Speer,C. A. 
and Fayer, R. (2015): Sarcocystosis of animals and humans, 2nd ed. CRC Press, Boca Raton, Florida, 512 p.

El-Dakhly, K.; El-Nesr, K.; El-Nahass, E.S.; Hirata, A.; Sakai, H. and Yanai, T. (2011): Prevalence and distribution patterns of Sarcocystis spp. in buffaloes in Beni-Suef, Egypt. Trop Anim Health Prod, 43:1549-15542.

EL-Mishmishy, B. (2017): Thesis Molecular Charactrizationof Sarcocystis species in sheep, Faculty of Vet. Med.AlMansoura University.

El-Seify, M.; El-Morsey, A.; Hilali, M.; Zayed, A.; El-Dakhly, K.; Haridy, M.; Sakai, H. and Yanai,T. (2014): Molecular characterization of sarcocytis fusiformis and sarcocystis buffalonis infecting water buffaloes (bubalus bubalis) from egypt. American Journal of Animal and Veterinary Sciences, 9(2):95-104.

FAO, (2013): livestock production. Food and Agriculture Organization. Rome, Italy.

Fayer, R.; Esposito, D.H. and Dubey, J. P. (2015): Human Infections with Sarcocystisspecies.Clin.Microbiol.Rev.

Ghoneim, Nahed. H.; Reda,Wafa. M. and Nader,Sara. M. (2014): Occurrence of Zoonotic Sarcosporidiosis in Slaughtered Cattle and Buffaloes in Different Abattoirs in Egypt. Global Veterinaria ,13 (5): 809-813.

Gjerde B.; Hilali,M.; Abbas, I.E. (2016): Molecular differe-ntiation of Sarcocystis buffalonis and Sarcocystis levinei in water buffaloes (Bubalus bubalis) from Sarcocystis hirsute and Sarcocystis cruzi in cattle (Bostaurus). Parasitol Res.
Hamidinejat, H.; Motamedi, H.; Alborzi, A. and Hatami, A. (2014): Molecular detection of Sarcocystis species in slaughtered sheep by PCR-RFLP from south-western of Iran. J. Parasit. Dis., 38(2): 233-237.

Hussein D.E.; Abu-Akkada S.S.; Bessat M.S.; Aggour M.G. and Otify Y.Z. (2017): Molecular identification of Sarcocystis species in imported frozen beef inEgypt.Alexandria Journal of Vet. Sciences. 53 (2): 72-82.

Kirkpatrick, L.A.and Feeney B.C. (2013): A simple guide to IBM SPSS statistics for version 20.0. Student ed. Belmont,Calif.:Wadsworth, Cengage Learning. Kotz, S. Bal.

Korany. Hanan,. Sayed (2016):Sarcocystosis in some meat and meat products; M.v.sc.thesis Degree, Beni-Suef Univ.,Fac.of Vet.Medicine, Food Hygiene Dep.

Mehlhorn, H. (2016): Animal parasites. Encyclopedia of Parasitology. Springer-Verlag Berlin Heidelberg 2016 H. Mehlhorn (ed.), DOI 10.1007/978-3-662-43978-4; 2:e41, doi:10.4081/ijfs.2013.e41.

Ministry of Agriculture, Veterinary Services Authority (1986): Meat Inspection Regulation, Egyptian Legal Notice No 517 for 1986.

Mohamed, Sara. A. (2013): Studies in some ruminant animals in Assiut; M.vs.c. degree parasitology Dept.,Vet.Medicine Faculty, Assiut Univ.

Motamedi, G.; Dalimi, A.; Nouri, A. and Aghaeipou, K. (2011): Ultrastructural and molecular characterization of Sarcocystis isolated from camel 
(Camelus dromedarius) in Iran.

Parasitol. Res., 108: 949-954.

Mousa, M. M.; Hiekal, Fatma.A; ElHoshy, Samia. M.; Radwan, Marawa, M. and Abd-El-Naby, Walaa. S. (2016): Characterization of Sarcocystis Species Based on Traditional and Molecular Methods in Imported Frozen Buffalo Meat in Egypt. Alexandria Journal of Veterinary Sciences, 51(1): 155-161.

Ortega and Cama (2018): Tropical Food borne parasites, Chapter 4, Cystoisospora belli and Sarcocystis spp. Springer International Publishing AG 201857 Y.R. Ortega, C.R. Sterling (eds.), Foodborne Parasites, Food Microbiology and Food Safety, DOI 10.1007/978-3-319-67664-7_4.

Paikari, H.; Dalimi, A.; Esmaeilzadeh M.; Valizadeh, M.; Karimi, G.; Motamedi, G. and Abdi Goudarzi, M. (2008): Identification of sarcocystis species of slaughtered sheep in qazvin. Modares J. Med. Sci., 11:65-72 (In Persian).

Silva, R.; Chunlei, S. and Langoni, H. (2009): First identification of Sarcocystis tenella by PCR in naturally infected sheep from Brazil. Vet Parasitol, 165: 332-336.

Wahba, A. A.; Ayoub, Mary. B. and Soliman,Khadra. M. (2014): Light and ultrastructure of Sarcocystis spp. of camels and associated pathological changes. Animal Health Research Journal, 2 (4): 143-158.

qazvin. Modares J. Med. Sci., 11:65-72 (In Persian).

Silva, R.; Chunlei, S. and Langoni, H. (2009): First identification of Sarcocystis tenella by PCR in naturally infected sheep from Brazil. Vet Parasitol, 165: 332-336.

Wahba,A.A.;Ayoub,Mary.B.andSoliman,Kha dra.M.(2014):Light and ultrastructure of Sarcocystis spp. of camels and associated pathological changes. Animal Health Research Journal, 2 (4): 143-158. 